\title{
PENINGKATAN MINAT, MOTIVASI DAN KESIAPAN BERWIRAUSAHA MASYARAKAT PEDUKUHAN NGRUNGGO, DESA GETAS, KECAMATAN PLAYEN, KABUPATEN GUNUNGKIDUL
}

\section{Increasing Interest, Motivation And Entrepreneurship Readiness Of Ngrunggo Community, Getas Village, Playen Subdistrict, Gunungkidul Regency}

\author{
Rubiyatno'), Theodorus Sutadi' ${ }^{2}$, Patrick Vivid Adinata ${ }^{\text {(), }}$, dan Ima Kristina Yulita ${ }^{4)}$ \\ 1)Program Studi Manajemen, Universitas Sanata Dharma \\ 2)Program Studi Manajemen, Universitas Sanata Dharma \\ 3)Program Studi Manajemen, Universitas Sanata Dharma \\ 4)Program Studi Manajemen, Universitas Sanata Dharma
}

Diterima 19 Juli 2020 / Disetujui 25 September 2020

\begin{abstract}
Ngrunggo vilage has abundant natural resources in the form of agricultural products namely cassava and corn. However, this potential has not been able to optimally increase the income of citizens. The women villager in the village already have sufficient skills to produce processed products from cassava. However, they still feel hesitant to develop the cassava chip business seriously. This community service aims to provide insight about entrepreneurship, as well as generate interest, motivation and increase entrepreneurship readiness for women villagers on Ngrunggo, Getas village, Playen district, Gunung Kidul regency. The method used is group counseling or group approach that is a counseling that is related to the target group counseling. The results of this service show that participants have an adequate interest, motivation and entrepreneurial readiness to run a business. Although the interests, motivations and readiness are still in the form of attitude, not in the form of action.
\end{abstract}

Keywords: interest, motivation, entrepreneurship readiness, entrepreneurship

\begin{abstract}
ABSTRAK
Dusun Ngrunggo memiliki sumber daya alam yang melimpah berupa hasil pertanian yakni ketela dan jagung. Namun potensi tersebut belum mampu menambah penghasilan warga secara optimal. Ibu-ibu di dusun tersebut sudah memiliki ketrampilan yang memadai untuk memproduksi hasil olahan dari singkong. Akan tetapi mereka masih merasa ragu untuk mengembangkan usaha kripik dengan serius. Pengabdian kepada masyarakat ini bertujuan untuk memberikan wawasan mengenai kewirausahaan, serta membangkitkan minat, motivasi dan meningkatkan kesiapan berwirausaha bagi ibu ibu warga dusun Ngrunggo, desa Getas, kecamatan Playen, kabupaten Gunung Kidul. Metode yang digunakan adalah penyuluhan kelompok atau group approach yaitu suatu penyuluhan yang berhubungan dengan sasaran penyuluhan secara kelompok. Hasil pengabdian in menunjukkan bahwa peserta memiliki minat, motivasi dan kesiapan berwirausaha yang memadai untuk menjalankan usaha. Walaupun minat, motivasi dan kesiapan tersebut masih dalam bentuk sikap, belum berupa tindakan.
\end{abstract}

Kata kunci : minat, motivasi, kesiapan berwirausaha, kewirausahaan

Coresponding Author: imakristina@usd.ac.id 


\section{PENDAHULUAN}

\section{a. Latar Belakang}

Dusun Ngrunggo merupakan dusun yang memiliki sumber daya alam yang melimpah berupa hasil pertanian yakni ketela dan jagung. Mata pencaharian utama yang menjadi sumber penghasilan bagi masyarakat dusun tersebut adalah petani dan peternak. Potensi hasil pertanian berupa ketela pohon belum mampu menambah penghasilan warga secara optimal. Ketela pohon, atau yang lebih dikenal dengan singkong atau ubi kayu, merupakan pohon tahunan tropika dan subtropika dari keluarga Euphorbiaceae. Umbinya dikenal luas sebagai makanan pokok penghasil karbohidrat dan daunnya sebagai sayuran. Ketela pohon merupakan tanaman yang mampu bertahan hidup di daerah dan kondisi iklim yang sulit sehingga menjadikan singkong sebagai salah satu sumber bahan makanan terpenting di negara-negara tropis dan negara berkembang (Hartati et al, 2008).

Singkong merupakan tanaman yang mudah dibudidayakan dan tidak memerlukan biaya tinggi dalam perawatannya serta memiliki beberapa manfaat dalam kehidupan sehari-hari. Manfaat tersebut antara lain : daun singkong dapat digunakan sebagai pakan ternak maupun sayuran, batang singkong dapat digunakan sebagai bibit atau sebagai kayu bakar jika sudah kering dan umbi singkong dapat diolah menjadi berbagai jenis makanan olahan (Handayani dan Sundari, 2016).

Di Indonesia, ketela pohon menjadi makanan pokok setelah beras dan jagung. Manfaat daun ketela pohon sebagai bahan sayuran memiliki protein cukup tinggi, atau untuk keperluan yang lain seperti bahan obat-obatan. Kayunya bisa digunakan sebagai pagar kebun atau di desa-desa sering digunakan sebagai kayu bakar untuk memasak. Dengan perkembangan teknologi, ketela pohon dijadikan bahan dasar pada industri makanan dan bahan baku industri pakan. Selain itu, digunakan pula pada industri obat-obatan.

Ibu-ibu di dusun Ngrunggo saat ini, sebagian sudah mulai memanfaatkan hasil pertanian berupa ketela pohon. Mereka membuat kripik dari ketela. Pemasaran kripik tersebut saat ini masih terbatas di sekitar tempat tinggal mereka. Ketersediaan bahan yang ada dan ketrampilan yang memadai dalam membuat produk kripik dari ketela pohon ternyata tidak cukup untuk membuat potensi tersebut menjadi sarana untuk meningkatkan pendapatan masyarakat. Ibu-ibu masih hangat-hangat tai ayam dalam menjalani usaha rumah tangga dengan memproduksi kripik. Ibu-ibu tidak melakukan produksi kripik secara teratur, kadang produksi kadang tidak. Hal itu terjadi karena adanya perasaan takut apabila tidak laku. Melihat hal tersebut maka perlu dibangkitkan kembali minat, motivasi dan kesiapan kewirausahaan.

$$
\text { Menurut Suryana (2013:16), }
$$

kewirausahaan adalah usaha untuk menciptakan nilai tambah dengan jalan mengombinasikan sumber-sumber melalui cara-cara baru dan berbeda untuk memenangkan persaingan. Nilai tambah tersebut dapat diciptakan dengan cara mengembangkan teknologi dan ilmu pengetahuan, menghasilkan barang dan jasa sehingga lebih efisien, memperbaiki produk dan jasa yang sudah ada, dan menemukan cara untuk memberikan kepuasan kepada konsumen. Kewirausahaan atau entrepreneurship adalah usaha kreatif yang dibangun berdasarkan inovasi untuk menghasilkan sesuatu yang baru, memiliki nilai tambah, memberi manfaat, menciptakan lapangan kerja dan hasilnya berguna bagi orang lain (Soegoto, 2010). Sedangkan wirausaha merupakan orang yang melihat adanya peluang kemudian menciptakan organisasi untuk memanfaatkan peluang tersebut (Alma, 2013). Seorang wirausaha harus bisa melihat suatu peluang dari perspektif yang berbeda dari orang lain atau yang 
tidak terpikirkan oleh orang lain yang kemudian bisa diwujudkan menjadi value (Dharmawati, 2016 : 6).

Menurut Ilik (2010) dalam Dharmawati (2016:15) terdapat beberapa keuntungan dan kerugian ketika seseorang memilih menjadi seorang wirausaha. Keuntungannya adalah (1) memiliki otonomi yang luas dalam mengelola usaha, (2) peluang untuk mengembangkan konsep usaha yang dapat menghasilkan keuntungan yang sangat memotivasi wirausaha, (3) bebas dalam mengelola keuangan dan (4) memiliki legitimasi moral yang kuat untuk mewujudkan kesejahteraan dan menciptakan kesempatan kerja. Sedangkan kerugiannya adalah (1) pengorbanan personal karena harus bekerja dengan waktu lama dan sibuk terutama diawal usaha, (2) beban tanggungjawab karena wirausaha harus mengelola semua fungsi bisnis baik pemasaran, keuangan, personil maupun pengadaan dan pelatihan, dan (3) kecilnya marjin keuntungan dan kemungkinan gagal.

Berkaitan dengan minat kewirausahaan dapat dijelaskan dengan menjelaskan arti minat. Minat adalah seperangkat mental yang terdiri dari suatu campuran perasaan, harapan, pendirian, dan kecenderungan yang mengarahkan individu kepada suatu pilihan tertentu. Minat mempengaruhi proses dan hasil belajar seseorang sebab jika seseorang tersebut mempelajari sesuatu dengan penuh minat maka dapat diharapkan hasilnya akan lebih baik. Selain itu, minat seseorang dapat diekspresikan melalui pernyataan yang menunjukkan seorang lebih tertarik pada suatu obyek lain (Suhartini, 2011). Minat seseorang untuk berwirausaha dapat muncul jika ia memiliki informasi dan pengetahuan mengenai kewirausahaan lalu menekuni bidang usaha tertentu. Selain itu, kisah sukses dari orang lain juga dapat menginspirasi seseorang untuk berwirausaha.
Minat berwirausaha dipengaruhi oleh faktor internal maupun faktor eksternal. Faktor internal berasal dari dalam diri wirausahawan dapat berupa sifat-sifat personal, sikap, kemauan dan kemampuan individu yang dapat memberi kekuatan untuk berwirausaha. Faktor eksternal dapat berupa lingkungan keluarga, lingkungan dunia usaha, lingkungan fisik, lingkungan social ekonomi dan lain-lain (Komsi, 2013)

Minat warga negara Indonesia untuk menjadi wirausaha masih lebih rendah dibandingkan negara-negara lain di Kawasan Asia Tenggara. Pada awal September 2020 jumlah wirausaha di Indonesia masih kurang dari 3\%, sedangkan Singapura sudah 7\%, Malaysia sudah $6 \%$ dan Thailand sudah 5\% (https://economy.okezone.com, 2020). Wirausaha memiliki peran penting bagi kemajuan perekonomian suatu negara antara lain menciptakan lapangan kerja baru, meningkatkan pendapatan nasional, menciptakan nilai tambah barang dan jasa, mengurangi kesenjangan social dan ekonomi serta membantu terciptanya masyarakat adil makmur (https://www.kabarbisnis.com, 2020).

Berkaitan dengan motivasi kewirausahaan dapat dijelaskan dengan menjelaskan arti kata motivasi. Motivasi berasal dari bahasa latin movere yang berarti dorongan daya penggerak atau kekuatan yang menyebabkan suatu tindakan atau perbuatan. Motivasi merupakan suatu kekuatan yang mendorong orang untuk terlibat dalam perilaku terentu daripada perilaku lainnya (Steward dan Brown, 2011). Steward dan Brown (2011) juga menunjukkan bahwa motivasi biasanya diwakili oleh tiga elemen yaitu pilihan perilaku, intensitas dan ketekunan. Pilihan perilaku berkaitan dengan keputusan untuk melakukan tindakan tertentu. Intensitas menunjukkan seberapa besar upaya untuk melakukan tindakan tersebut. Ketekunan menunjukkan berapa lama akan terus melakukan tindakan tersebut.

Seseorang melakukan suatu tindakan pada umumnya mempunyai sifat 
positif (Suwatno, 2011). Kesiapan diri pribadi seseorang diperlukan ketika memasuki dunia wirausaha. Seseorang yang tidak siap mental memasuki dunia usaha akan merasa tertekan dengan kondisi lingkungannya seperti malu apabila bertemu dengan orang lain teman, maupun kerabat (Nitisusastro, 2009: 82).

Berkaitan dengan kesiapan kewirausahaan, Dalyono (2005: 52) menyebutkan bahwa kesiapan adalah kemampuan yang cukup baik fisik dan mental. Kesiapan fisik berarti tenaga yang cukup dan kesehatan yang baik, sementara kesiapan mental berarti memiliki minat dan motivasi yang cukup untuk melakukan suatu kegiatan. Seseorang yang berminat memasuki dunia usaha sebaiknya sejak awal telah mempersiapkan diri dengan berbagai bekal yang diperlukan dalam menjalankan kegiatan usaha. Dengan adanya peningkatan minat, motivasi dan kesiapan berwirausaha maka diharapkan ibu ibu akan bergairah kembali dalam melakukan usaha kripik singkong dan pada akhirnya mampu meningkatkan kesejahteraan keluarga.

\section{b. Identifikasi Masalah}

Pada saat ini, ibu-ibu memiliki ketrampilan yang memadai untuk memproduksi hasil olahan dari singkong serta tersedia singkong yang cukup melimpah di dusun Ngrunggo. Akan tetapi mereka masih merasa ragu untuk mengembangkan usaha kripik yang mereka miliki dengan serius. Oleh karena itu, perlu suntikan yang berkaitan dengan minat, motivasi dan kesiapan berwirausaha, supaya dapat tergerak untuk menjadi lebih serius dan sungguh sungguh dalam menjalani usaha kripik singkong.

\section{c. Tujuan dan Manfaat}

Tujuan kegiatan adalah memberikan wawasan mengenai kewirausahaan, serta membangkitkan minat, motivasi, dan meningkatkan kesiapan berwirausaha bagi ibu ibu warga dusun Ngrunggo, desa Getas, kecamatan Playen, Kabupaten Gunung Kidul.

Manfaat dari kegiatan ini adalah ibuibu memiliki wawasan lebih luas mengenai kewirausahaan semakin termotivasi dan semakin siap untuk berwirausaha.

\section{METODE PENELITIAN}

Kegiatan pengabdian yang berupa penyuluhan dilaksanakan pada hari Selasa tanggal 23 Juli 2019. Penyuluhan merupakan suatu kegiatan mendidik orang atau kegiatan pendidikan yang bertujuan untuk mengubah perilaku klien sesuai dengan yang direncanakan/ dikehendaki sehingga orang semakin modern. Hal ini merupakan usaha mengembangkan atau memberdayakan suatu potensi individu klien agar lebih berdaya secara mandiri (Mardikanto, 1992). Dalam pengabdian ini digunakan metode penyuluhan kelompok. Menurut Setiana (2005), metode penyuluhan kelompok atau group approach merupakan suatu penyuluhan yang berhubungan dengan sasaran penyuluhan secara kelompok. Metode ini lebih menguntungkan karena memungkinkan adanya umpan balik, dan interaksi kelompok yang memberi kesempatan bertukar pengalaman maupun pengaruh terhadap perilaku dan norma para anggotanya.

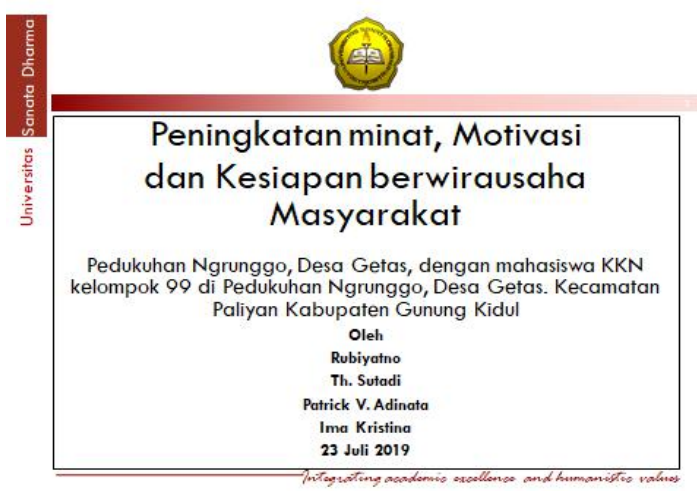

Gambar 1. Judul Materi Penyuluhan (sumber : Dokumentasi Pribadi, 2019) 
Kelebihan metode penyuluhan kelompok adalah relatif lebih efisien, dan komunikator tidak tersamar. Sedangkan kelemahannya adalah kurang bisa memperhatikan masing masing individu secara lebih dekat. Kegiatan pengabdian ini meliputi beberapa langkah. Langkah-langkah tersebut adalah sebagai berikut :

1. Ceramah tentang gambaran kewirausahaan

2. Ceramah tentang teori minat dan motivasi berwirausaha

3. Ceramah tentang kesiapan berwirausaha

4. Memberikan contoh-contoh produk makanan yang berbasis pada singkong dan bahan lain dengan menggunakan media gambar dan cerita keberhasilan di tempat lain

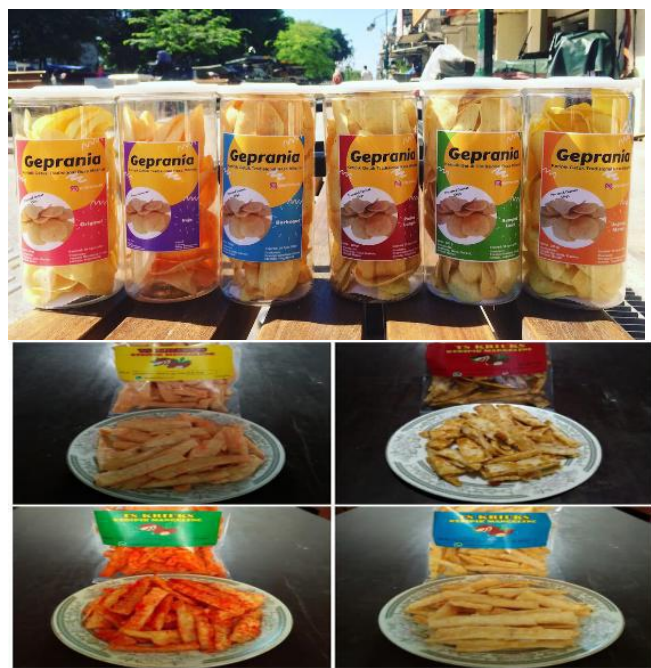

Gambar 2. Produk Olahan singkong

(Sumber : internet, 2019)

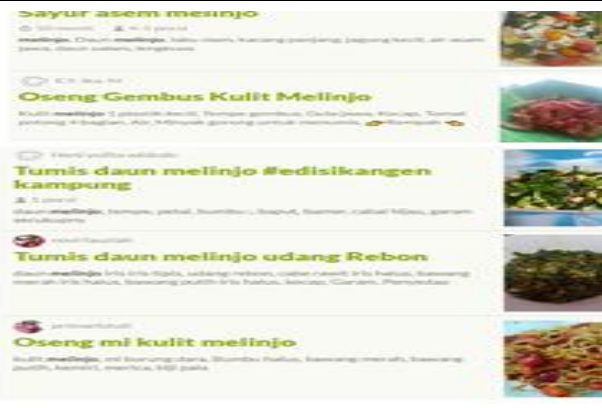

Gambar 3. Produk Olahan Melinjo

(Sumber : internet, 2019)

5. Tanya jawab, untuk memperdalam pemahaman yang pada akhirnya mampu mengubah sikap peserta

6. Dilanjutkan dengan menguji sejauh mana minat, motivasi dan kesiapan berwirausaha para ibu dengan dibantu menjawab persetujuan mereka dengan pernyataan-penyataan untuk mengetahui minat seperti yang dikembangkan oleh Suhartini (2011) dan motivasi oleh Suwatno (2011) dan kesiapan berwirausaha oleh Dalyono (2005), seperti terlihat dalam tabel 1.

Tabel 1. Pernyataan tentang minat, motivasi dan kesiapan berwirausaha

\begin{tabular}{|l|l|}
\hline No & \multicolumn{1}{|c|}{ Pernyataan } \\
\hline 1 & Saya memiliki minat untuk memulai sebuah usaha \\
\hline 2 & $\begin{array}{l}\text { Saya bangga terhadap diri saya dan optimis dalam } \\
\text { mencapai suatu tujuan }\end{array}$ \\
\hline 3 & Saya dapat menerima saran dan kritik dari orang lain \\
\hline 4 & Saya senang melakukan suatu hal yang baru \\
\hline 5 & $\begin{array}{l}\text { Saya yakin berwirausaha dapat mengajarkan tanggung } \\
\text { jawab, kerja keras, dan percaya diri }\end{array}$ \\
\hline 6 & $\begin{array}{l}\text { Saya yakin dapat melaksanakan suatu pekerjaan dengan } \\
\text { baik }\end{array}$ \\
\hline 7 & $\begin{array}{l}\text { Saya dapat belajar mengambil sebuah keputusan yang baik } \\
\text { ketika berwirausaha }\end{array}$ \\
\hline 8 & $\begin{array}{l}\text { Menurut saya kerja keras diperlukan untuk mencapai } \\
\text { kesuksesan }\end{array}$ \\
\hline 9 & Saya menyukai kreativitas \\
\hline 10 & $\begin{array}{l}\text { Saya bangga ketika memperoleh keuntungan dari hasil } \\
\text { usaha saya sendiri. }\end{array}$ \\
\hline 11 & Saya ingin membuka lapangan pekerjaan bagi orang lain \\
\hline 12 & $\begin{array}{l}\text { Saya ingin menjadi wirausaha yang sukses dan akan } \\
\text { berusaha keras untuk mencapainya }\end{array}$ \\
\hline 13 & $\begin{array}{l}\text { Saya yakin berwirausaha akan membuat saya menjadi } \\
\text { mandiri }\end{array}$ \\
\hline
\end{tabular}

\section{HASIL DAN PEMBAHASAN}

Kegiatan pengabdian masyarakat yang dilakukan dengan penyuluhan kepada 
kelompok ibu-ibu di dusun Ngrunggo secara umum mendapatkan respon yang sangat baik dari peserta. Selama acara penyuluhan berlangsung, mereka menyimak secara serius dan memberikan feedback secara langsung apabila ada yang kurang dipahami atau menanyakan kepada pemberi materi kalau ada yang dianggap kurang sesuai dengan pemahaman peserta..

Hasil dari kegiatan ini adalah pemahaman peserta tentang gambaran umum kewirausahaan yang menurut kami cukup ditangkap dengan baik. Hal ini dilihat dari respon mereka saat ditanya tentang esensi dari wirausaha. Mereka menyadari bahwa wirausaha memerlukan kreatifitas, tidak mudah menyerah dan ketekunan. Selain itu, mereka menyadari bahwa dengan melakukan usaha maka akan berhadapan dengan risiko yang berupa ketidakpastian di masa yang akan datang. Risiko umumnya berbanding lurus dengan keuntungan yang diharapkan. Jika ingin memperoleh keuntungan yang besar maka harus berhadapan dengan risiko yang besar dan sebaliknya jika ingin memperoleh keuntungan sedikit maka akan berhadapan dengan risiko yang kecil. Oleh karena itu, seorang wirausaha akan selalu berproses untuk mengambil risiko guna memperoleh hasil yang diinginkan. Dalam hal ini, ibuibu di dusun Ngrunggo juga perlu berlatih mengambil risiko misalnya dengan berani membuat produk berbahan baku singkong dan memasarkannya ke daerah sekitar atau ke luar daerah Gunungkidul.

Menurut Fahmi (2013:97) terdapat empat cara untuk mengelola risiko yaitu : (1) memperkecil risiko yaitu membatasi setiap keputusan yang memiliki risiko tinggi, (2) mengalihkan risiko misalnya dengan mengasuransikan bisnis guna menghindari risiko yang tidak diketahui kapan waktunya, (3) mengontrol risiko yaitu dengan cara melakukan kebijakan mengantisipasi terhadap muculnya risiko sebelum risiko itu terjadi, (4) pendanaan risiko yaitu dengan menyediakan dana cadangan guna mengantisipasi munculnya risiko di kemudian hari.
Berkaitan dengan minat berwirausaha, para peserta merasa memiliki minat untuk memulai sebuah usaha, bangga terhadap diri mereka sendiri dan optimis dalam mencapai suatu tujuan, dapat menerima saran dan kritik dari orang lain dan senang melakukan suatu hal yang baru. Hal-hal tersebut merupakan sebagian dari petunjuk bahwa sesorang berminat berwirausaha. Namun pemahaman saja tidak cukup sehingga perlu dilanjutkan dengan tindakan nyata, yang menurut kami memerlukan pendampingan secara konsisten. Menurut Suryana (2013), minat berwirausaha dapat muncul karena adanya motif berprestasi yaitu hasrat untuk mencapai hasil terbaik guna mencapai kepuasan pribadi.

Berkaitan dengan motivasi berwirausaha, para peserta merasa yakin berwirausaha dapat mengajarkan tanggung jawab, kerja keras, dan percaya diri, yakin dapat melaksanakan suatu pekerjaan dengan baik, dapat belajar mengambil sebuah keputusan yang baik ketika berwirausaha, kerja keras diperlukan untuk mencapai kesuksesan dan menyukai kreativitas. Halhal tersebut merupakan sebagian dari petunjuk bahwa sesorang memiliki motivasi berwirausaha. Namun ungkapan yang diperoleh melalui isian tersebut masih berupa pemahaman belum berupa tindakan, maka masih diperlukan agar pemahaman atau sikap tersebut dapat diwujudkan dalam tindakan.

Pada umumnya seseorang memerlukan motivasi yang tinggi untuk menjadi seorang wirausahawan sehingga bisa mengubah hidupnya dari tidak memiliki usaha menjadi memiliki usaha (Fahmi, 2013 : 12). Motivasi untuk memulai usaha dan siap menghadapi risiko adalah gambaran awal menuju wirausahawan. Ketika seseorang tidak siap menghadapi risiko sebaiknya ia memilih bisnis-bisnis sederhana dengan risiko yang kecil.

Ada dua jenis motivasi menurut Siregar dan Nara (2011) yaitu : (1) motivasi intrinsik yang berasal dari dalam diri seseorang tanpa adanya rangsangan dari 
luar, (2) motivasi ekstrinsik yang berasal dari luar misalnya pemberian hadiah dan factor-faktor eksternal yang memiliki daya dorong motivasional. Menurut pengamatan kami para ibu-ibu telah memiliki motivasi internal untuk mulai berwirausaha namun masih memerlukan daya dorong dari luar supaya mereka memiliki keberanian dalam membuat serta memasarkan produknya secara konsisten. Mereka juga masih perlu didampingi agar dapat lebih kreatif dalam menciptakan varian produk baru.

Sedangkan berkaitan dengan kesiapan berwirausaha para peserta merasa yakin berwirausaha akan membuat saya menjadi mandiri, ingin menjadi wirausaha yang sukses dan akan berusaha keras untuk mencapainya, ingin membuka lapangan pekerjaan bagi orang lain dan bangga ketika memperoleh keuntungan dari hasil usaha saya sendiri. Uraian tersebut menunjukkan bahwa mereka siap untuk berwirausaha, hal itu ditunjukkan dengan antusiasnya mereka dalam bertanya, komentar dan merespon tugas yang diberikan selama penyuluhan.

Para peserta yang telah memiliki minat, motivasi dan kesiapan berwirausaha perlu dilengkapi dengan entrepreneurial mindset. Menurut McGraith \& Mac Millan (2000) dalam Kasali, dkk (2010) ada tujuh karakter yang perlu dimiliki seorang calon wirausaha yaitu : (1) berorientasi pada tindakan dengan tidak membiarkan suatu kesempatan berlalu begitu saja, (2) berpikir simple dengan melihat persoalan secara jernih dan menyelesaikan masalah tahap demi tahap, (3) selalu mencari peluangpeluang baru, (4) mengejar peluang dengan disiplin tinggi, (5) hanya mengambil peluang terbaik, (6) fokus pada eksekusi, dan (7) memfokuskan energi setiap orang pada bisnis yang sedang digeluti.

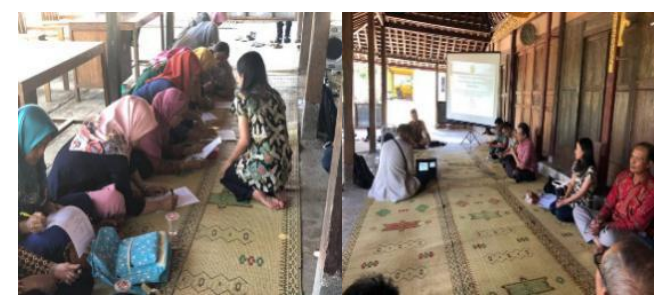

\section{Gambar 4. Suasana penyuluhan}

(Sumber : Data Pribadi, 2019)

Dalam pelaksanaan pengabdian kepada masyarakat ini tentu tidak berjalan tanpa kendala. Beberapa kendala yang dihadapi antara lain: (1) Tingkat pendidikan ibu-ibu yang sangat bervariasi dengan sehingga akan tidak mudah memberikan penyuluhan terutama dalam memberikan contoh-contoh peristiwa yang berkaitan dengan pengelolaan usaha dan (2) Waktu yang terbatas dalam pelaksanaan kegiatan yaitu hanya satu hari penyuluhan.

\section{SIMPULAN}

Kegiatan pengabdian ini mampu berkontribusi dalam meningkatkan pemberdayaan masyarakat dalam bidang minat, motivasi dan kesiapan berwirausaha. Adanya bekal minat, motivasi dan kesiapan berwirausaha yang meningkat pada akhirnya akan membuat para ibu tergerak hatinya untuk memulai usaha dengan lebih serius sehingga akan terjadi peningkatan penghasilan bagi masyarakat di dusun Ngrunggo.

Berdasarkan evaluasi yang telah dilakukan dapat diajukan beberapa saran sebagai berikut :

1. Waktu pelaksanaan kegiatan pengabdian perlu ditambah agar tujuan kegiatan dapat tercapai sepenuhnya, tetapi dengan konsekuensi penambahan biaya pelaksanaan. Oleh karena itu biaya PPM sebaiknya tidak sama antara beberapa tim pengusul proposal, mengingat khalayak sasaran yang berbeda pula.

2. Kegiatan pengabdian ini dapat berlanjut dengan pendampingan usaha misalnya dalam hal pemasaran yang meliputi 4 
3. yaitu produk, place, price dan promosi, sehingga keberlanjutan usaha akan terjaga.

\section{DAFTAR PUSTAKA}

Alma, Buchari. (2013). Kewirausahaan. Cetakan ke 19. Bandung: Alfabeta.

Dharmawati, Made. (2016).Kewirausahaan. Jakarta : PT RajaGrafinfo Persada.

Fahmi, Irham. (2013). Kewirausahaan : Teori, Kasus dan Solusi. Bandung : Alfabeta.

Handayani, Sugiharti Mulya dan Mei Tri Sundari. (2016). Pemberdayaan Wanita Tani Melalui Pembuatan Keripik Belut Daun Singkong Di Kecamatan Jumantono Kabupaten Karanganyar. Jurnal DIANMAS. Vol.5, No. 1. Hal 23-34.

Hartati, L. Kurniasari dan M.E. Yulianto. (2008). Inaktivasi Enzimatis Pada Produksi Linamarin Dari Daun Singkong Sebagai Senyawa Anti Neoplastik. Momentum. Vol. 4, No. 2. hal 1-6

Kasali, Renald. (2010). Modul Kewirausahaan. Jakarta : Penerbit Hikmah.

Komsi, K. (2013). Analisis Pengaruh Faktor Eksternal dan Internal terhadap Minat Berwirausaha. Proceeding PESAT (Psikologi, Ekonomi, Sastra, Arsitektur \& Teknik Sipil), 1-8.

Mardikanto, T. (1992). Penyuluhan Pengembangan

Pertanian. Surakarta : Sebelas Maret Press.

Nitisusastro, Mulyadi. (2012). Perilaku Konsumen. Bandung : Alfabeta
Yuniarsih, Tjutju dan Suwatno. (2011). Manajemen Sumber Daya Manusia Teori, Aplikasi, dan Isu Penelitian. Bandung: Alfabeta.

Setiana, L. (2005). Teknik Penyuluhan Dan Pemberdayaan Masyarakat. Bogor : Ghalia Indonesia

Soegoto, Eddy Soeryanto. (2010). Enterpreneurship Menjadi Pebisnis Ulung (edisi revisi). Jakarta : Kompas Gramedia

Stewart, Greg L. dan Kenneth G. Brown. 2011. Human Resource Management Linking Strategy to Practice. $2^{\text {nd }}$ Edition. John Willey \& Sons Inc.

Suhartini, Yati. (2011). Analisis FaktorFaktor Yang Mempengaruhi Minat Mahasiswa dalam Berwiraswasta. Jurnal Akmenika UPY, Vol. 7, 2011.

Suryana. (2013). Kewirausahaan Kiat dan Proses Menuju Sukses. Jakarta: Salemba Empat.

https://economy.okezone.com/read/2020/09 /08/455/2274550/saatnya-bangunjumlah-pengusaha-indonesiatertinggal-jauh-dari-negaratetangga diakses tanggal 24 September 2020

https://www.kabarbisnis.com/read/2897671 jumlah-wirausaha-indonesiaditargetkan-4-persen-pada-2030 diakses tanggal 24 September 2020 